\title{
Sesame and flaxseed oil: nutritional quality and effects on serum lipids and glucose in rats
}

\author{
Óleo de linhaça e gergelim: qualidade nutricional e efeitos sobre lipídios e glicose séricos em ratos
}

\author{
Rita de Cássia Avellaneda GUIMARÃES ${ }^{1 *}$, Maria Lígia Rodrigues MACEDO², Cláudia Leite MUNHOZ \\ Wander FILIU ${ }^{3}$, Luís Henrique VIANA ${ }^{4}$, Vanessa Taís NOZAKI ${ }^{1}$, Priscila Aiko HIANE ${ }^{2}$
}

\begin{abstract}
This study evaluated the nutritional value of sesame and flaxseed oils and their effects on the lipid and glucose profile of rats fed diets containing different fat combinations. Fatty acid composition, refractive index, and iodine and saponification values were analyzed to characterize the oils. In the biological assay, Wistar rats were fed different diets, whose fat composition consisted of varying combinations of flaxseed oil, sesame oil, and animal fat. The primary constituents of the sesame oil were oleic (28.6\%), linoleic (28.4\%), and lauric acid (14.6\%); for the flaxseed oil they were alpha-linolenic (39.90\%), oleic (17.97\%) and linoleic acid (12.25\%). The iodine and saponification values of the oils were within the reference range. Rats fed flaxseed oil-based diets had the lowest serum cholesterol values, whereas rats fed diets with flaxseed oil + sesame oil + animal fat had the highest glucose levels. HDL levels decreased significantly with flaxseed oil. Sesame and flaxseed oils are sources of polyunsaturated fatty acids (PUFA), and the flaxseed oil-based diet had a hypocholesterolemic effect, whereas sesame oil showed oxidative stability since it contains high levels of monounsaturated and saturated fatty acids.
\end{abstract}

Keywords: diets; flaxseed; sesame; lipids; nutritional quality index.

\section{Resumo}

Este estudo avaliou o valor nutricional do óleo de gergelim e de linhaça e seus efeitos sobre o perfil lipídico e glicose de ratos alimentados com dietas contendo diferentes combinações de gordura. Perfil de ácidos graxos, índice de refração, iodo e saponificação foram analisados para caracterizar os óleos. No ensaio biológico, ratos Wistar foram alimentados com diferentes dietas, cuja composição de gordura foi composta de combinações distintas de óleo de linhaça, gergelim e gordura animal. Os principais constituintes do óleo de sésamo foram: oleico (28,6\%), linoleico $(28,4 \%)$ e láurico (14,6\%); para o óleo de linhaça, foram: alfalinolênico (39,90\%), oleico (17,97\%) e linoleico (12,25 \%). Valores de iodo e saponificação dos óleos ficaram dentro do intervalo de referência. Ratos alimentados com óleo de linhaça nas dietas tiveram menores valores de colesterol sérico, enquanto que ratos alimentados com óleo de linhaça + óleo de gergelim + gordura animal obtiveram mais altos níveis de glicose. Níveis de HDL diminuíram significativamente com óleo de linhaça. Óleo de gergelim e linhaça são fontes de AGPI, e a dieta contendo óleo de linhaça teve um efeito hipocolesterolêmico, e no óleo de gergelim verificou-se estabilidade oxidativa, uma vez que este contém altos níveis de monoinsaturados e ácidos graxos saturados.

Palavras-chave: dietas; linhaça; gergelim; lipídios; índice de qualidade nutricional.

\section{Introduction}

Abnormal lipid metabolism is a main cause of dyslipidemia, which is a major risk factor for cardiovascular disease, obesity, cholestasis, and overall mortality. It is well known that diet plays an important role in the control of cholesterol homeostasis (MORISE et al., 2004; FERNANDES et al., 2010). It has been reported that vegetable oils have been used as food and for medicinal purposes for hyperlipidemia and that they may be useful adjuncts to reduce the risk of cardiovascular disease and alterations in liver metabolism. Recent studies have demonstrated that ingestion of polyunsaturated fatty acids (PUFA) present in vegetable oils, is inversely related to the incidence of heart disease by decreasing cholesterol and plasma triglyceride levels (GALVÃO et al., 2008).
Arteriosclerotic vascular disease (ASVD) is associated to genetic factors, sex, age, smoking, sedentary lifestyle, overweight, hypertension, dyslipidemia, and diabetes, but this and other cardiovascular disorders can be prevented by controlling dietary fat and cholesterol levels. Current recommended fat intakes are based on fat quality rather than amount (RAPOSO, 2010). In this respect, some types of fat such as PUFAs from the omega 3 $(\omega-3)$ family have gained importance as functional food.

Omega-3 PUFAs are primarily found in fish, especially in twait shad, salmon, tuna, and anchovies (WHELAN; RUST, 2006). Another important source of PUFA is flaxseed obtained from Linum usitatissimum plants (Linaceae family), cropped mainly in Argentina, Brazil, Canada, China, India. and Turkey

${ }^{1}$ Postgraduation Program in Health and Development in the Middle West Region, Universidade Federal de Mato Grosso do Sul - UFMS, CEP 79070-900, Campo Grande, MS, Brazil,e-mail: ritaaguimaraes@gmail.com

2 Department of Food Technology and Public Health, Universidade Federal de Mato Grosso do Sul - UFMS, Campo Grande, MS, Brazil

${ }^{3}$ Department of Pharmacy, Universidade Federal de Mato Grosso do Sul - UFMS, Campo Grande, MS, Brazil

${ }^{4}$ Laboratory of Fuels, Universidade Federal de Mato Grosso do Sul - UFMS, Campo Grande, MS, Brazil

${ }^{*}$ Corresponding author 
(SAMMOUR, 1999). Flaxseed is a flat, oval-shaped seed (CHUNG; LEI; LI-CHAN, 2005; MARQUES et al., 2011) whose oil contains 53\% alpha-linolenic acid (ALA), an essential $\omega-3$ fatty acid (UNITED STATES..., 2006). Flaxseed is also a good source of dietary fiber (20-25\%) (VIJAIMOHAN et al., 2006) and lignans $(>500 \mu \mathrm{g} / \mathrm{g})$, which are plant steroids analogous to mammalian estrogen (STODOLNIK et al., 2005).

Polyunsaturated fatty acids from the n-6 ( $\omega-6)$ family, found in nuts, seeds, and vegetable oils such as corn and soybean oils (INSTITUTE..., 2005), are also important. While $\omega$-3 PUFAs are precursors of 3-series prostanoids and 5 -series leukotrienes (associated to anti-inflammatory and antithrombotic properties), $\omega-6$ PUFAs are precursors of 2 -series prostanoids and 4-series leukotrienes (associated to pro-inflammatory and prothrombotic activity) (McKENNEY; SICA, 2007).

Sesame seed (Sesamum indicum L.), another widely consumed seed, is a good $\omega-6$ source. This Pedaliaceae is cropped in both tropical and subtropical countries. India and China are the major producers accounting for $70 \%$ of world production. In Brazil, 13,000 tons of sesame seeds are produced over nearly 20,000 ha, yielding approximately 650 kg/ha (ARRIEL; VIEIRA; FIRMINO, 2005). Sesame oil has advantages over other vegetable oils owing to its high nutritional and therapeutic value. Sesame seeds, which are used in traditional Indian (Ayurvedic) and Chinese medicine, contain 57\% highly stable oil (RESHMA et al., 2010). Due to its high oxidative stability, sesame oil is added to margarines, salads, and frying oils (YEN; LAY, 1990). Saturated fatty acid (SFA) content in sesame oil is nearly $14 \%$, comparable to soy and corn oil. Oleic and linoleic (LA) acid levels are approximately $45 \%$, which is close to that found in corn, soy, and cottonseed oil (EMBRAPA, 2001).

The Institute of Medicine (2005) developed Dietary Reference Intakes (DRIs) to evaluate adequate fatty acid intake based on the mean consumption of the American population. It recommends that the adequate daily intake of omega- 6 is $17 \mathrm{~g}$ for men and $12 \mathrm{~g}$ for woman; and for $\omega-3$, these values are $1.6 \mathrm{~g}$ for men and $1.1 \mathrm{~g}$ for women. The beneficial effects of diets containing long chain $\omega-3$ fatty acids (PUFA) justify the regular inclusion of this ingredient in human diet although the conversion of ALA to eicosapentaenoic acid (EPA) and docosahexaenoic acid (DHA), the main therapeutic agents of $\omega-3$ fatty acids, is only around 6\% (BURDGE, 2006).

Both flaxseed and sesame seed are nutritional supplements, representing an excellent source of PUFA that can promote cardioprotective effects if consumed daily (CHUNG; LEI; LICHAN, 2005). A number of studies in rats have investigated the functional properties of their lipid fraction, but the implications of fatty acid ratio in health have been scarcely investigated. As such, the present study evaluated the nutritional value of sesame and flaxseed oils and their effects on the lipid and glucose profile of rats fed diets with different oil combinations.

\section{Materials and methods}

\subsection{Oil extraction}

Flaxseed and sesame seeds were obtained from a commercial dealer in Campo Grande, MS, Midwest Region, Brazil. The seeds were ground using a Turratec mill and passed through a Tamis 60 (drum sieve). The oil fraction of the flaxseed and sesame meals produced was extracted with a solvent mixture containing a 2:1:0.8 ratio of methanol: chlorophorm: distilled water (BLIGH; DYER, 1959). The oil extracted was chemically characterized and used to formulate the experimental diets combined with animal fat obtained from a conventional supplier.

\subsection{Animals and experimental design}

Wistar rats (Rattus norvegicus) weaned at 21 days of age and weighing $79.49 \pm 0.50 \mathrm{~g}$ were separated into 8 groups of 6 animals each. The groups received one of 8 diets designed to support growth, with similar protein and fat content and formulated according to the American Institute of Nutrition (AIN) (REEVES; NIELSEN; FAHEY, 1993). The diets had similar composition except for fat source, which consisted of different proportions of linseed oil, sesame oil, and animal fat. The rats were given ad libitum access to food and water. The control group (Group C) was given commercial feed (Nuvilab CR-1). Diet composition was analyzed to ensure that caloric and macronutrient balance was in accordance with AIN-93C.

The fat source of the experimental diets consisted of soybean oil for group $G_{C}$ (control); animal fat for $G_{A}$; flaxseed oil for $\mathrm{G}_{\mathrm{F}}$; sesame oil for $\mathrm{G}_{\mathrm{S}}$; animal fat + flaxseed oil for $\mathrm{G}_{\mathrm{AF}}$; animal fat + sesame oil for $G_{A S}$; flaxseed oil + sesame oil for $G_{F S}$; and animal fat + flaxseed oil + sesame oil for $\mathrm{G}_{\mathrm{AFS}}$. Diet ingredients were sieved to produce homogeneous diets with similar granulometry. The antioxidant TBHQ was used to minimize PUFA oxidation in the diets.

Diets were elaborated according to reference values and contained $200 \mathrm{~g}$ caseine, $132 \mathrm{~g}$ dextrinized starch, $397 \mathrm{~g}$ corn starch, $50 \mathrm{~g}$ cellulose, $100 \mathrm{~g}$ sucrose, $7 \mathrm{~g}$ fat, $2.5 \mathrm{~g}$ choline bitartrate, $35 \mathrm{~g}$ mineral mixture, $10 \mathrm{~g}$ vitamin mixture, and $3 \mathrm{~g}$ L-cystine per kilogram.

The experiment lasted 45 days; the first 5 days used to adapt the rats to the diets. Animals were weighed once a week, and food intake was measured daily by calculating the difference between the amount of food provided and the non-consumed portion. Feed efficiency (weight gain/feed intake) was also calculated.

At the end of the experiment, the rats were anesthetized for blood collection and subsequently killed. Blood samples were centrifuged to obtain serum fractions, which were stored at $-18{ }^{\circ} \mathrm{C}$ until analysis.

The present study was carried out in accordance with regulations and ethical guidelines established by the "Colégio Brasileiro de Experimentação Animal (COBEA)", and the experimental protocol was approved by the CEUA/UFMS Ethics Committee for Animal Use (Protocol 272). 


\subsection{Serum analysis}

Total cholesterol and its fractions, triglycerides, and blood glucose were determined in serum samples using enzymecolorimetric methods with specific kits and spectrophotometric measurements (HAGEN; HAGEN, 1962; FLEG, 1973; CAREY; FELBRUEGGE; WESTGARD, 1974).

\subsection{Fatty-acid composition of seed oils}

To determine fatty acid composition from sesame seed and flaxseed lipid, the extracted oils were saponified, esterified, and transferred to hexane, according to the Hartman and Lago (1973) method modified by Maia and Rodriguez-Amaya (1993). Fatty acid methyl esters were analyzed using a Shimadzu GC-2010 chromatograph with AOC-5000 autoinjector and flame ionization detector (FID). A Restek Stabilwax-DA fusedsilica bonded-phase column $(30 \mathrm{~m} \times 0.25 \mathrm{~mm} ; 0.25 \mu \mathrm{m})$ was used, with both injector and FID operated at $250{ }^{\circ} \mathrm{C}$. Initial oven temperature of $80^{\circ} \mathrm{C}$ was maintained for 3 minutes and then raised to $140{ }^{\circ} \mathrm{C}$ at a rate of $10^{\circ} \mathrm{C} /$ minutes and to $240{ }^{\circ} \mathrm{C}$ at $5{ }^{\circ} \mathrm{C} /$ minutes, which was kept for 11 minutes. Methyl ester peaks were identified by comparing their retention times on the column with those of standard fatty acid methyl esters. Quantification was determined using the area correction factor (MAIA; RODRIGUEZ-AMAYA, 1993; HOLLAND et al., 1994).

\subsection{Physicochemical characterization of the oils}

Seed lipid content was determined by Soxhlet extraction with hexane. The refractive index was obtained using an Abbe direct reading refractometer. To determine iodine value, the oil was placed in an erlenmeyer flask with carbon tetrachloride and Wijs solution. The final solution was titrated with sodium thiosulfate until it turned from black to pink. To determine saponification value, flaxseed and sesame oil were placed in beakers and added with $\mathrm{KOH}$. After the addition of phenolphthalein, the solutions were titrated with $\mathrm{HCl}$ until the pink color disappeared. All of the assays were performed in triplicate and according to methods of the American Oil Chemists' Society (1998).

\subsection{Nutritional quality index}

Nutritional quality, using five different indexes, was evaluated based on the fatty acid composition of the oils. The atherogenic index (AI) (Equation 1) and the thrombogenic index (TI) (Equation 2) considered the monounsaturated acid (MUFA) levels and were based on Ulbricht and Southgate (1991). The hypocholesterolemic: hypercholesterolemic ratio (HH) (Equation 3) was calculated according to Santos, Bessa and Santos (2002). The PUFA:SFA and $\omega 6: \omega 3$ ratios were also calculated.

$A I=\frac{C_{12: 0}+4 \times C_{14: 0}+C_{16: 0}}{\sum M U F A+\sum \varpi 6+\sum \varpi 3}$

Atherogenicity Index (AI).
$T I=\frac{C_{14: 0}+C_{16: 0}+C_{18: 0}}{0.5 \times \sum M U F A+0.5 \times \sum \varpi 6+3 \times \sum \varpi 3}$

Thrombogenicity Index (TI).

$H H=\frac{C_{18: 1 C i 39}+C_{18: Z \varpi 6}+C_{20: 4 \pi 6}+C_{18: 3 \pi 3}+C_{20: 5 \pi 3}+C_{22: 5 \pi 3}+C_{22: 6 \pi 3}}{C_{14: 0}+C_{16: 0}}$

Hypocholesterolemic: Hypercholesterolemic ratio $(\mathrm{HH})$.

\subsection{Statistical analysis}

Data were analyzed using analysis of variance complemented by the Tukey test. Significance level was set at 0.05 and analyzed by one-way analysis of variance (ANOVA).

\section{Results and discussion}

\subsection{Fatty acid composition}

Table 1 shows fatty acid composition of the oils. Some studies on sesame oil reported $8.63 \%$ myristic acid for cultivar CNPA G2, 9.08\% for CNPA G3 and 8.71\% for Seridó, but lauric acid was not detected in these varieties (ANTONIASSI et al., 1997). Ünal and Yalçın (2008) found $8.46 \pm 0.10 \%$ palmitic acid and $4.93 \pm 0.10 \%$ stearic acid in sesame oil, similar to the values reported in the present study. Embrapa (2001) reports that sesame cultivars CNPA G2, CNPA G3, and CNPA G contain $40.66,38.53$ and $42.27 \%$ oleic acid and $44.57,46.71$ and $41.72 \%$ linoleic acid (LA), respectively, higher values than those found

Table 1. Fatty acid content (mean $\pm \mathrm{sd}$ ) of sesame oil and flaxseed oil.

\begin{tabular}{|c|c|c|}
\hline Fatty acid & Sesame oil (\%) & Flaxseed oil (\%) \\
\hline \multicolumn{3}{|l|}{ Saturated (SFA) } \\
\hline Caprylic (C8:0) & $3.22 \pm 0.27$ & - \\
\hline Capric (C10:0) & $2.06 \pm 0.12$ & - \\
\hline Lauric (C12:0) & $14.59 \pm 0.49$ & - \\
\hline Myristic (C14:0) & $4.38 \pm 0.13$ & - \\
\hline Palmitic (C16:0) & $7.49 \pm 0.04^{\mathrm{a}}$ & $4.72 \pm 0.04^{\mathrm{b}}$ \\
\hline Heptadecanoic (C17:0) & $0.03 \pm 0.02$ & - \\
\hline Stearic $(\mathrm{C} 18: 0)$ & $4.04 \pm 0.06^{\mathrm{a}}$ & $4.59 \pm 0.05^{\mathrm{a}}$ \\
\hline Arachidonic (C20:0) & $0.35 \pm 0.01^{\mathrm{a}}$ & $0.18 \pm 0.02^{\mathrm{b}}$ \\
\hline Behenic (C22:0) & $0.08 \pm 0.01^{\mathrm{a}}$ & $0.17 \pm 0.03^{\mathrm{b}}$ \\
\hline Lignoceric (C24:0) & $0.11 \pm 0.01^{\mathrm{a}}$ & $0.25 \pm 0.01^{\mathrm{b}}$ \\
\hline Total SFA & $36.43^{\mathrm{a}}$ & $9.97^{\mathrm{b}}$ \\
\hline \multicolumn{3}{|l|}{ Monounsaturated (MUFA) } \\
\hline Oleic $(\mathrm{C} 18: 1 \omega-9)$ & $28.59 \pm 0.44^{\mathrm{a}}$ & $17.97 \pm 0.09^{\mathrm{b}}$ \\
\hline 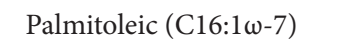 & $0.08 \pm 0.01^{\mathrm{a}}$ & $0.06 \pm 0.05^{\mathrm{b}}$ \\
\hline Vaccenic $(\mathrm{C} 18: 1 \omega-7)$ & $0.52 \pm 0.01^{\mathrm{a}}$ & $0.60 \pm 0.01^{\mathrm{b}}$ \\
\hline Gadoleic (C20:1n9) & - & $0.03 \pm 0.05$ \\
\hline Total MUFA & $28.59^{\mathrm{a}}$ & $18.0^{\mathrm{b}}$ \\
\hline \multicolumn{3}{|l|}{ Polyunsaturated (PUFA) } \\
\hline Linoleic $(\mathrm{C} 18: 2 \omega-6)$ & $28.35 \pm 0.46^{\mathrm{a}}$ & $12.25 \pm 0.05^{\mathrm{b}}$ \\
\hline 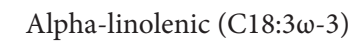 & $0.29 \pm 0.01^{\mathrm{a}}$ & $39.90 \pm 0.14^{\mathrm{b}}$ \\
\hline 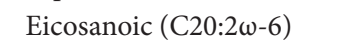 & $0.05 \pm 0.01^{\mathrm{a}}$ & $0.09 \pm 0.08^{\mathrm{b}}$ \\
\hline Total PUFA & $28.69^{a}$ & $52.24^{\mathrm{b}}$ \\
\hline
\end{tabular}

Non-detected fatty acids are indicated by a dash (-). Different letters in a same row indicate statistical differences $(\mathrm{p}<0.05)$. 
in the present study. Uzun et al. (2007) found 45.3\% LA and $37.0 \%$ oleic acid in sesame oil, but they found no linolenic acid fractions.

Omega-3 and $\omega-6$ fatty acids are eicosanoid precursors that regulate immune and inflammatory functions. Some essential fatty acid (EFA) derivatives, such as dihomo-gammalinolenic and arachidonic acid, both from the $\omega-6$ series, and EPA, from the $\omega-3$ series, are especially important because they are lipid mediators involved in many physiological functions (KRUMMEL, 2007).

Long chain fatty acids are incorporated into cell membranes in the following order: EPA and DHA ( $\omega-3)$, arachidonic acid ( $\omega-6)$, and oleic acid ( $\omega-9)$. In addition to the effects on membrane stability and fluidity, $\omega-3$ and $\omega-6$ are eicosanoid precursors, lipid-soluble inflammatory mediators that are one of the main routes of fatty acid activity (WAITZBERG; BORGES, 2005). Long chain fatty acids also participate in the mediation of many molecular signals involved in cholesterol metabolism (KÖKTEN et al., 2010).

Earlier studies on flaxseed oil report higher PUFA levels than those obtained in the present study. Epaminondas (2009) found $7.06 \%$ palmitic acid and Vijaimohan et al. (2006) found more than 51\% ALA, 17\% LA and 18\% oleic acid. Choo, John and Dufour (2007) analyzed 3 flaxseed varieties and found ALA values ranging from 54 to $59.6 \%$. However, Peiretti and Meineri (2008) found $2.9 \%$ palmitic, $0.3 \%$ oleic, $5.8 \%$ LA, and $32.8 \%$ ALA levels in flaxseed oil, lower values than those reported here.

The sum of SFA and MUFA was higher in sesame oil than in flaxseed oil. However, the sum of MUFA and PUFA was higher in flaxseed oil than in sesame oil. This indicates that flaxseed oil is a good source of fatty acids with cardioprotective properties. According to the American Heart Association (2004), an adult should consume $20-23 \%$ PUFA and $10 \%$ SFA daily. The oils reported in the present study meet these standards and can therefore be added to diet.

The human body usually makes use of dietary fatty acids. However, it is capable of producing SFA and MUFA from glucose and amino acids through enzymatic elongation (addition of 2 carbon units) and desaturation (formation of new double bonds). Desaturation activity is stimulated by insulin and inhibited by glucose, adrenalin, and glucagon (KRISETHERTON, 2006).

The incorporation of essential fatty acids may cause structural and functional changes in the phospholipidic membrane, affecting important biological processes such as the synthesis of inflammatory mediators, including eicosanoids (COSTUNER; KARABABA, 2008).

Recent studies have expressed increasing interest in PUFA as essential components of the human diet. They have been shown to play an essential role in a number of biological systems, combating coronary and degenerative disorders. Besides being structural components of cell membranes, PUFA play an important role in regulatory function, acting as a source of eicosanoids and prostaglandins are the predominant component (RAMADAN et al., 2009). In addition, PUFA are the primary bio-membrane components, including the plasma membrane, endoplasmic reticulum, and mitochondrial membrane (KAITHWAS; MAJUMDAR, 2010).

\subsection{Nutritional quality indexes}

Nutritional quality of sesame seed and flaxseed lipid fractions evaluated by the different indexes is shown in Table 2.

Diets with a PUFA:SFA ratio below 0.45 are considered inadequate (LONDON, 1984) because of their potential to increase blood cholesterol levels. In the present study, it was found PUFA:SFA ratio of 0.79 in sesame oil and 5.25 in flaxseed oil indicating that these oils have good fatty acid balance.

Determination of the $\omega 6: \omega 3$ ratio is important for human heath since excessive consumption of $\omega 6$, accompanied by decreased ingestion of $\omega 3$, is a risk factor for cardiovascular disorders. These fatty acids compete for enzymes involved in desaturation reactions and chain elongation. Although these enzymes have greater affinity for fatty acids from the $\omega-3$ series, the conversion of linolenic acid into long-chain PUFA is strongly affected by dietary linolenic acid levels (RAMADAN et al., 2009). Thus, the $\omega 6: \omega 3$ ratio of 97.80 found in sesame oils is within the range of $5: 1$ to $10: 1$ recommended by the WHO (WORLD..., 1995). The ratio obtained for flaxseed was 0.31 , which is below the recommended level.

Indexes based on the functional properties of the different fatty acids allow better evaluation of the nutritional quality of foods. Although these indexes have not been applied to evaluate edible oils, they have been used to evaluate fish meat. As such, a number of studies on fish meat were mentioned here for comparison purposes.

The $\mathrm{HH}$ index considers specific effects of fatty acids on cholesterol metabolism, and high $\mathrm{HH}$ values are desired from a nutritional standpoint. In the present study, $\mathrm{HH}$ was 4.82 for sesame oil and 14.85 for flaxseed oil, much higher values than those reported for fish from the Brazilian Pantanal, (1.49-1.84) and considered quite high for an animal product (RAMOS FILHO et al., 2008).

The AI (atherogenic index) and TI (thrombogenic index) indexes are considered cardiovascular disease risk factors. Thus, these indexes must be kept low. AI and TI were lower than 1 for both sesame and flaxseed oil due to the cardioprotective effect of their PUFA. Ramos Filho et al. (2008) also found AI and TI values below 1.0 for Pantanal fish, except for pacu fish, which had a TI of 1.16 .

Table 2. Evaluation of sesame and flaxseed oil by nutritional quality indexes.

\begin{tabular}{lcc}
\hline \multicolumn{1}{c}{ INDEX } & Sesame oil & Flaxseed oil \\
\hline PUFA:SFA ratio & 0.79 & 5.24 \\
$\omega 6: \omega 3$ ratio & 97.80 & 0.31 \\
atherogenicity index (AI) & 0.69 & 0.07 \\
thrombogenicity index (TI) & 0.13 & 0.07 \\
hypocholesterolemic: & 4.82 & 14.85 \\
hypercholesterolemic ratio $(\mathrm{HH})$ & & \\
\hline
\end{tabular}




\subsection{Physicochemical properties of the oils}

Seed lipid content, the refractive index, and iodine and saponification values of sesame and flaxseed oils are shown in Table 3. Total lipid content in flaxseed is within the $30-50 \mathrm{~g} \cdot \mathrm{kg}^{-1}$, range reported in earlier studies (ROTHENBURG; PEREIRA, 2006; VIJAIMOHAN et al., 2006; MATHEWS et al., 2000). Lipid content in the sesame seeds was higher than that obtained in earlier studies on national and imported seed varieties, which did not exceed $54.7 \%$ oil yield (EMBRAPA, 2001; RESHMA et al., 2010; UZUN et al., 2007).

The refractive index was $1.465 \pm 0.01$ for sesame oil and $1.474 \pm 0.01$ for flaxseed oil. These values are comparable to the refractive index of cottonseed oil (1.458 to 1.466), rapeseed oil (1.465 to 1.467), corn oil (1.465 to 1.468) and soy oil (1.466 to 1.470) (CORSINI; JORGE, 2006).

The refractive index reflects the relationship between the speed of light in the air and in the oil. This value increases with chain length and fatty acid unsaturation and is associated to the iodine index (ORDONEEZ-PEREDA, 2005). Flaxseed oil has more units of long-chain fatty acids (over 16 carbons) and unsaturations than sesame oil. Thus, the refractive index of flaxseed oil $(1.474 \pm 0.01)$ is higher than that of sesame oil $(1.465 \pm 0.01)$.

The reference values proposed by the AOCS (AMERICAN..., 1998) for flaxseed oil are $170 \mathrm{~g} \mathrm{I}_{2} \mathrm{~kg}^{-1}$ for the iodine index and $196 \mathrm{mg} \mathrm{KOH} \mathrm{kg}{ }^{-1}$ for the saponification index, higher values than those observed in the present study. Similarly, ANVISA (AGÊNCIA..., 1999) reported an iodine value of $104 \mathrm{~g} \mathrm{I}_{2} \mathrm{~kg}^{-1}$ and saponification value of $195 \mathrm{mg} \mathrm{KOH} \mathrm{kg}{ }^{-1}$ for sesame oil, higher values than those found in the present study. Discrepancies among the studies are likely associated to different SFA and UFA levels in the oil samples analyzed, which vary according to the region in which the seeds were produced and inherent climatic, soil, and management conditions.

Since saponification value is related to the length of the fatty acid chain, it therefore decreases with the molecular weight of the fatty acid (CECCHI, 2003). Sesame oil has a higher sum of SFA (36.43\%) than flaxseed oil (9.97\%), confirming the proportionality of the saponification index, which was also higher for sesame oil.

\subsection{Weight evolution}

In the 3 first weeks of the experiment, the groups fed the experimental diets had higher weight gain than those in the control group $\left(\mathrm{G}_{\mathrm{C}}\right)$, which were fed the commercial $\operatorname{diet}$ (Table 4 ,

Table 3. Physicochemical characteristics (mean \pm sd) of sesame oil and flaxseed oil.

\begin{tabular}{lcr}
\hline \multicolumn{1}{c}{ Characteristic } & Sesame oil & \multicolumn{1}{c}{ Flaxseed oil } \\
\hline Lipid Contents $\left({\left.\mathrm{g} . \mathrm{kg}^{-1}\right)}^{\circ}\right.$ & $56.50 \pm 0.67^{\mathrm{a}}$ & $39.52 \pm 0.36^{\mathrm{b}}$ \\
Refractive Index at $40^{\circ} \mathrm{C}$ & $1.465 \pm 0.01^{\mathrm{a}}$ & $1.474 \pm 0.01^{\mathrm{a}}$ \\
Iodine Value $\left(\mathrm{g} \mathrm{I}_{2} \mathrm{~kg}^{-1}\right)$ & $90.17 \pm 0.75^{\mathrm{a}}$ & $123.19 \pm 0.09^{\mathrm{b}}$ \\
Saponification Value $\left.(\mathrm{mg} \mathrm{KOH} \mathrm{kg})^{-1}\right)$ & $416.78 \pm 1.07^{\mathrm{a}}$ & $511.90 \pm 1.59^{\mathrm{b}}$ \\
\hline Different letters in a same row indicate statistical differences $(\mathrm{p}<0.05)$.
\end{tabular}

$p<0.05)$. Animals fed experimental diets grew faster, probably because they adapted faster. From the 4th to the 6th week, the rats in the experimental groups continued gaining more weight than the control rats $(p<0.05)$, except for $\mathrm{G}_{\mathrm{AFS}}$, whose diet was likely less palatable.

\subsection{Blood parameters}

Consuming diets enriched with animal fat increases the risk of cardiovascular diseases causing hyperlipidemia and ASVD in addition to augmenting LDL-cholesterol levels over time (ONODY et al., 2003). Table 5 shows that glucose levels were higher in $G_{A F S}$ than in $G_{C}, G_{A}, G_{A F}, G_{S}$, and $G_{A S}(p>0.05)$, and that $\mathrm{G}_{\mathrm{F}}$ and $\mathrm{G}_{\mathrm{FS}}$ had intermediary values $(\mathrm{p}<0.05)$.

Marques et al. (2011) reported that the combination of flaxseed and flaxseed oil in rat diet produces lower glucose levels $\left(160.8 \pm 33.6 \mathrm{mg} \cdot \mathrm{dL}^{-1}\right)$ than that of diets containing only roasted flaxseed $\left(180.4 \pm 35.4 \mathrm{mg} \cdot \mathrm{dL}^{-1}\right)$ or flaxseed oil $\left(185.2 \pm 65.7 \mathrm{mg} \cdot \mathrm{dL}^{-1}\right)$, probably because flaxseed provides a high content of soluble and insoluble fibers that contributes to decreased glucose and triglyceride levels, while flaxseed oil confers cardioprotective benefits. Other in vivo beneficial effects of flaxseed are promoted by lignans associated to its fiber matrix. Lignans, which participate in the inactivation of free radicals from fatty acids and reactive oxygen species, have an indirect in vivo effect on endogenous antioxidant systems such as glutathione (FERNANDES et al., 2010).

Baba et al. (2000) reported that rats fed sesame oil-based diets exhibited higher glucose levels $\left(120.09 \pm 5.00 \mathrm{mg} \cdot \mathrm{dL}^{-1}\right)$ than those fed diets based on soybean oil $\left(109 \pm 6.08 \mathrm{mg} \cdot \mathrm{dL}^{-1}\right)$ and rapeseed oil $\left(96.9 \pm 6.19 \mathrm{mg} \cdot \mathrm{dL}^{-1}\right)$. Ramesh (2011) showed that the glycemic index of rats treated with sesame oil-based diet for 42 days decreased from $80.15 \pm 4.32$ to $76.18 \pm 3.68 \mathrm{mg} . \mathrm{dL}^{-1}$ in normoglycemic rats and from $242.85 \pm 7.49$ to $222.02 \pm 8.27 \mathrm{mg}$. $\mathrm{dL}^{-1}$ in diabetic rats.

Cholesterol levels were lower in $G_{F}$ than in $G_{S}$ and $G_{A S}$ $(\mathrm{P}<0.05)$, and the other groups showed intermediary values $(p>0.05)$. Omega- 3 fatty acids found in flaxseed oil contribute to increase cholesterol excretion via bile, thus depleting the liver cholesterol pool and increasing the synthesis of free cholesterol (MORISE et al., 2004). In addition, diets containing ALA

Table 4. Mean weight gain, food intake and feed efficiency $( \pm s d ; n=6)$ in rats fed experimental diets based on different fat sources for 45 days.

\begin{tabular}{clcc}
\hline Group & Weight gain $(\mathrm{g})$ & Food intake $(\mathrm{g})$ & Feed efficiency $(\mathrm{g})$ \\
\hline $\mathrm{G}_{\mathrm{C}}$ & $208.60^{\mathrm{b}} \pm 6.69$ & $14.87^{\mathrm{b}} \pm 8.99$ & 14.03 \\
$\mathrm{G}_{\mathrm{A}}$ & $258.07^{\mathrm{a}} \pm 17.17$ & $15.88^{\mathrm{a}} \pm 3.44$ & 16.25 \\
$\mathrm{G}_{\mathrm{F}}$ & $273.52^{\mathrm{a}} \pm 11.85$ & $15.05^{\mathrm{a}} \pm 14.76$ & 18.17 \\
$\mathrm{G}_{\mathrm{AF}}$ & $281.17^{\mathrm{a}} \pm 10.70$ & $15.77^{\mathrm{a}} \pm 10.44$ & 17.83 \\
$\mathrm{G}_{\mathrm{S}}$ & $254.67^{\mathrm{a}} \pm 27.97$ & $15.09^{\mathrm{a}} \pm 12.54$ & 16.88 \\
$\mathrm{G}_{\text {AS }}$ & $260.59^{\mathrm{a}} \pm 11.82$ & $15.04^{\mathrm{a}} \pm 11.01$ & 17.33 \\
$\mathrm{G}_{\mathrm{FS}}$ & $279.23^{\mathrm{a}} \pm 11.79$ & $14.99^{\mathrm{a}} \pm 7.22$ & 18.63 \\
$\mathrm{G}_{\text {AFS }}$ & $271.38^{\mathrm{a}} \pm 27.57$ & $15.07^{\mathrm{a}} \pm 7.89$ & 18.01 \\
\hline
\end{tabular}

The diets were based on: $\mathrm{G}_{\mathrm{C}}=$ soybean oil; $\mathrm{G}_{\mathrm{A}}=$ animal fat; $\mathrm{G}_{\mathrm{F}}=$ flaxseed oil; $\mathrm{G}_{\mathrm{AF}}=$ animal fat + flaxseed oil; $G_{S}=$ sesame oil; $G_{A S}=$ animal fat + sesame oil; $G_{F S}=$ flaxseed oil + sesame oil; $\mathrm{G}_{\mathrm{AFS}}=$ animal fat + flaxseed oil + sesame oil. Different letters in a column indicate statistical difference between the groups $(\mathrm{p}<0.05)$. 
Table 5. Mean values $( \pm \mathrm{sd} ; \mathrm{n}=10)$ for blood parameters (in $\left.\mathrm{mg} \cdot \mathrm{dL}^{-1}\right)$ in rats fed diets with different fat composition for 45 days.

\begin{tabular}{ccccccc}
\hline Groups & Glucose & Total cholesterol & HDL-c & LDL- c & VLDL-c & Tryglyceride \\
\hline $\mathrm{G}_{\mathrm{C}}$ & $144.83^{\mathrm{b}} \pm 27.23$ & $57.00^{\mathrm{ab}} \pm 1.67$ & $51.17^{\mathrm{a}} \pm 2.79$ & $5.98^{\mathrm{ab}} \pm 0.58$ & $5.00^{\mathrm{c}} \pm 1.67$ & $25.83^{\mathrm{c}} \pm 7.83$ \\
$\mathrm{G}_{\mathrm{A}}$ & $177.83^{\mathrm{b}} \pm 41.92$ & $58.00^{\mathrm{ab}} \pm 4.98$ & $45.17^{\mathrm{abc}} \pm 4.88$ & $6.43^{\mathrm{a}} \pm 1.28$ & $11.00^{\mathrm{bc}} \pm 3.52$ & $54.50^{\mathrm{bc}} \pm 16.91$ \\
$\mathrm{G}_{\mathrm{F}}$ & $207.17^{\mathrm{ab}} \pm 42.52$ & $47.33^{\mathrm{b}} \pm 5.75$ & $39.67^{\mathrm{c}} \pm 3.82$ & $5.08^{\mathrm{ab}} \pm 0.95$ & $14.83^{\mathrm{bc}} \pm 5.08$ & $74.83^{\mathrm{abc}} \pm 25.65$ \\
$\mathrm{G}_{\mathrm{AF}}$ & $172.67^{\mathrm{b}} \pm 56.22$ & $59.83^{\mathrm{ab}} \pm 3.06$ & $44.83^{\mathrm{abc}} \pm 1.83$ & $4.95^{\mathrm{ab}} \pm 2.19$ & $27.00^{\mathrm{a}} \pm 12.18$ & $135.17^{\mathrm{a}} \pm 61.34$ \\
$\mathrm{G}_{\mathrm{S}}$ & $198.33^{\mathrm{b}} \pm 36.03$ & $63.17^{\mathrm{a}} \pm 6.11$ & $48.67^{\mathrm{abc}} \pm 2.66$ & $4.38^{\mathrm{ab}} \pm 1.32$ & $22.00^{\mathrm{ab}} \pm 5.29$ & $109.50^{\mathrm{ab}} \pm 25.67$ \\
$\mathrm{G}_{\mathrm{AS}}$ & $191.17^{\mathrm{b}} \pm 58.86$ & $62.00^{\mathrm{a}} \pm 14.14$ & $49.00^{\mathrm{ab}} \pm 8.58$ & $4.50^{\mathrm{ab}} \pm 2.40$ & $22.17^{\mathrm{ab}} \pm 9.66$ & $110.50^{\mathrm{ab}} \pm 47.79$ \\
$\mathrm{G}_{\mathrm{FS}}$ & $209.50^{\mathrm{ab}} \pm 38.84$ & $55.00^{\mathrm{ab}} \pm 10.39$ & $43.33^{\mathrm{abc}} \pm 7.58$ & $4.12^{\mathrm{ab}} \pm 1.16$ & $18.50^{\mathrm{ab}} \pm 3.83$ & $92.83^{\mathrm{ab}} \pm 19.17$ \\
$\mathrm{G}_{\text {AFS }}$ & $288.00^{\mathrm{a}} \pm 65.16$ & $54.50^{\mathrm{ab}} \pm 5.72$ & $41.83^{\mathrm{bc}} \pm 2.23$ & $3.62^{\mathrm{b}} \pm 1.18$ & $15.67^{\mathrm{abc}} \pm 3.72$ & $78.33^{\mathrm{abc}} \pm 18.80$ \\
\hline
\end{tabular}

The diets were based on: $G_{C}=$ soybean oil; $G_{A}=$ animal fat; $G_{F}=$ flaxseed oil; $G_{A F}=$ animal fat + flaxseed oil; $G_{S}=$ sesame oil; $G_{A S}=$ animal fat + sesame oil; $G_{F S}=$ flaxseed oil + sesame oil; $\mathrm{G}_{\mathrm{AFS}}=$ animal fat + flaxseed oil + sesame oil. Different letters in a column indicate statistical difference between the groups $(\mathrm{p}<0.05)$.

decrease fat accumulation in the liver because the acid stimulates the $\beta$-oxidation of fatty acids and inhibits their synthesis (RAMADAN et al., 2009; ALMEIDA; BOAVENTURA; GUSMAN-SILVA, 2009). Improving lipid metabolism by enhancing substrate mobilization and $\beta$-oxidation in the liver, as well as PUFA rich diets such as those containing flaxseed oil, might promote a cardioprotective effect (BASBAG; TONCER; BASBAG, 2009). On the other hand, animal fat consumption stimulates phospholipid biosynthesis, possibly because it decreases phospholipase activity or increases phospholipid volume triggering an inflammatory process (BASBAG; TONCER; BASBAG, 2009).

HDL-c levels were lower in $G_{F}$ than in $G_{C}(p<0.05)$, and the other groups exhibited similar intermediary values $(\mathrm{p}<0.05)$. Another study found HDL-c values of $54.0 \mathrm{mg} \cdot \mathrm{dL}^{-1}$ in rats fed brown flaxseed oil-based diets, $54.3 \mathrm{mg} \cdot \mathrm{dL}^{-1}$ with roasted flaxseed and $51.9 \mathrm{mg}$.dL ${ }^{-1}$ with crude flaxseed (MARQUES et al., 2011).

LDL-cholesterol levels were higher in $\mathrm{G}_{\mathrm{A}}$ than in $\mathrm{G}_{\mathrm{AFS}}$, likely because animal fat alone has greater potential to increase this cholesterol fraction than combined with the SFAs and MUFAs of sesame oil. Flaxseed oil action in $\mathrm{G}_{\mathrm{AFS}}$ was likely diminished by the high MUFA and SFA content. VLDL-c levels in turn were higher in $\mathrm{G}_{\mathrm{AF}}$ than in $\mathrm{G}_{\mathrm{C}}$ and $\mathrm{G}_{\mathrm{AFS}}(\mathrm{p}<0.05)$.

Despite the results obtained, the LDL/HDL ratio calculated to assess risk factors for ASVD (SOCIEDADE..., 2005) was below 1.0 in all treatments. Another study on rats fed flaxseed oil-based diets, HDL-c levels of $21.02 \pm 1.58 \mathrm{mg} . \mathrm{dL}^{-1}$, LDL-c of $47.59 \pm 3.37 \mathrm{mg} \cdot \mathrm{dL}^{-1}$ and VLDL of $13.46 \pm 1.46 \mathrm{mg} \cdot \mathrm{dL}^{-1}$ were found (VIJAIMOHAN et al., 2006).

Other studies demonstrated that the regular consumption of $\omega-3$ PUFA is efficient in reducing total cholesterol, cholesterol fractions, and triglycerides. However, humans with hypertriglyceridemia treated with dietary $\omega-3$ PUFA had a $45 \%$ increase in LDL-c levels ( 89 to $129 \mathrm{mg} \cdot \mathrm{dL}^{-1}$ ), contradicting the cardioprotective effects described for these fats (HARRIS et al., 2008; NAGAO; YANAGITA, 2008).

Fish oil is widely used because of its high $\omega$ - 3 content, the measurable effects it causes on blood serum as well as its capacity to reduce blood lipoproteins and mediate cellular inflammation. For instance, the consumption of 9 to $12 \mathrm{~g}^{-1}$ day of fish oil or 20 to $40 \mathrm{~g}^{-1}$ day of flaxseed oil improves lipid profile by decreasing plasma cholesterol (total and fractions) and the levels of inflammatory mediators and platelet aggregation (KAUL et al., 2008). However, 9 to 40 capsules of oil should be consumed daily to provide the health effects reported, which is not practical for consumers since dietary guidelines rarely suggest the consumption of more than 2 capsules per day of any compound. In addition, consumers seldom follow treatments with high doses of oil because the capsules have an unpleasant taste and frequently cause acid eructation (acid belching) (KAUL et al., 2008).

Daily supplementation with 20 to $50 \mathrm{~g}$ of flaxseed oil can decrease total cholesterol and LDL-c to normal levels in patients with hypercholesterolemia, and 38 to $40 \mathrm{~g}$ of ground flaxseed can reduce lipoprotein $\mathrm{A}$, apolipoprotein $\mathrm{A}-1$, and apolipoprotein $B$ values in postmenopausal women (RODRIGUES-LEVYA et al., 2010). However, overweight adults that consumed $50 \mathrm{~g}$ of chia seed (Salvia hipanica L.) did not decrease body measures, lipoproteins, serum EPA or DHA levels, but increased ALA levels (SENER et al., 2009).

Sener et al. (2009) reported that rats fed diets with $1 \%$ cholesterol supplemented with flaxseed and pumpkin seed $(33 \%$ $\mathrm{p} / \mathrm{p}$ ), followed by deprivation of $\omega-3$ fatty acids, and then fed diets with $5 \%$ flaxseed oil increased adipose tissue formation.

In the present study, rats fed flaxseed oil $\left(G_{F}\right)$ had higher HDL and lower LDL and VLDL levels compared to the findings reported by Morise et al. (2004), who studied the effects of flaxseed oil inclusion in rat diet. They found HDL of $32.8 \pm 0.27 \mathrm{mg} . \mathrm{dL}^{-1}$, LDL of $4.70 \pm 0.05 \mathrm{mg} . \mathrm{dL}^{-1}$ and VLDL of $3.00 \pm 0.05 \mathrm{mg} \cdot \mathrm{dL}^{-1}$.

As with cholesterol, elevated blood triglyceride levels damage vascular endothelial cells, causing cardiovascular disorders (WHELAN; RUST, 2006). Diets based on saturated fats increase triglyceride levels, and despite the increased lipase activity, fat accumulates in the liver (PELLIZZON et al., 2008). In the present study, triglyceride levels were higher in $\mathrm{G}_{\mathrm{AF}}$ and lower in $G_{C}$ and $G_{A}(p<0.05)$. No differences were detected between $G_{F}$ and $G_{A F S}$ or between $G_{S}, G_{A S}$, and $G_{F S}(p>0.05)$. Other studies on the triglyceride levels of Wistar rats as a function of the type of vegetable oil added to their diets reported $81 \mathrm{mg} \cdot \mathrm{dL}^{-1}$ for flaxseed oil-based diets, $70 \mathrm{mg} \cdot \mathrm{dL}^{-1}$ for rapeseed oil, $66 \mathrm{mg} . \mathrm{dL}^{-1}$ for soybean oil, $143 \mathrm{mg} \cdot \mathrm{dL}^{-1}$ for olive oil, and $106 \mathrm{mg} \cdot \mathrm{dL}^{-1}$ for diets based on sesame oil (MARQUES et al. 2011, BABA et al., 2000). 
Serum total cholesterol and LDL levels were lower in healthy adults that consumed flaxseed and sesame oils, but triglyceride levels were unaffected (CUNNANE et al., 1995). Tzang et al. (2009) reported that the consumption of vegetable oils containing PUFAs reduces triglyceride levels, probably because of increased lipase activity. Oxidation of fats and proteins from lipoproteins and cell membranes decreases fat transport causing cell damage and leading to heart disorders (APPOLINÁRIO et al., 2011). LDL transports cholesterol from the liver to peripheral arterial smooth muscle cells, and high LDL levels can cause cholesterol deposition within the arteries of the heart, a risk factor for the development of heart disease (MOREIRA et al., 2010; LUZIA; JORGE, 2011).

Although humans and other animals can synthesize SFA and MUFA, they lack the enzyme that inserts cis-double bounds in position 3 and 6 of fatty acids chain to synthesize ALA and LA, respectively. Both acids are part of the same metabolic pathway, competing for $\Delta^{6}$-desaturase, but they display different mechanisms of action. ALA exerts a major effect on the modulation of lipoproteins, whereas EPA and DHA decrease the synthesis of triglycerides and adiposity (POUDYAL et al., 2011). Moreover, as an essential fatty acid, ALA can be converted into EPA and DHA, and LA is a direct precursor of pro-inflammatory arachidonic acid (AA).

In the course of evolution, the $\omega-6: \omega-3$ ratio in human diet was probably similar in primordial times, but changes in eating habits, especially the dietary inclusion of LA-rich vegetable oils such as soybean, corn, sunflower, safflower, and cotton increased this proportion in the Western diet to at least 10:1 (POUDYAL et al., 2011). A reduction in the dietary $\omega-6$ : $\omega-3$ ratio can decrease the risk factors for developing metabolic syndrome. The effect of $\omega-6$ fatty acids on cardiovascular disease is still controversial. Some studies attribute the cardioprotective properties of $\omega-6$ fatty acids to their ability to decrease LDL-c levels, while others argue that the pro-inflammatory action of specific eicosanoids derived from AA is harmful. Irrespective of the amount of dietary $\omega-6$ fatty acid, there is growing acceptance that the inclusion of high levels of metabolically more active ALA and EPA, in addition to DHA, is important to reduce the risks of cardiovascular diseases (BROUGHTON; BAYES; CULVER, 2010).

\section{Conclusion}

The experimental diets supplemented with different fat sources increased weight gain compared with that of the control group. Group $\mathrm{G}_{\mathrm{AFS}}$ had the highest glucose, and $\mathrm{G}_{\mathrm{F}}$ had the lowest total cholesterol levels. HDL-c levels in groups $G_{C}, G_{F}, G_{A S}$, and $G_{A F S}$ changed significantly. LDL-c values were significantly different between $G_{A}$ and $G_{A F S}$, and VLDL-c differed between groups $G_{C}, G_{A F}$, and $G_{A F F}$. The triglyceride levels of $G_{A F}$ were higher than those of the other groups.

Flaxseed and sesame seeds have high lipid content and are a source of PUFA ( $\omega-3$ and $\omega-6)$, suggesting that they have cardioprotective properties. The nutritional quality of the seed oils assessed using AI, AT, HH, PUFA/SFA, and $\omega 6: \omega 3$ indexes indicate that sesame oil and flaxseed oils can be consumed as functional ingredients of human diet.

\section{Acknowledgements}

The authors are grateful for the technical-scientific support provided by the Coordenação de Apoio a Pesquisa de Ensino Superior (CAPES) and Universidade Federal do Mato Grosso do Sul (UFMS).

\section{References}

AGÊNCIA NACIONAL DE VIGILÂNCIA SANITÁRIA - ANVISA. Brasília: Ministério da Saúde, 1999.

ALMEIDA, K. C. L.; BOAVENTURA, G. T.; GUZMAN-SILVA, M. A. A linhaça (Linum usitatissimum) como fonte de ácido $\alpha$-linolênico na formação da bainha de mielina. Revista de Nutrição de Campinas, v. 22, n. 5, p. 747-754, 2009. http://dx.doi.org/10.1590/ S1415-52732009000500015

AMERICAN HEART ASSOCIATION. National Heart, Lung and Blood Institute/American Diabetes Association Conference on Scientific Issues Related to Management. Circulation, v. 109, p. 551-56, 2004. PMid:14757684. http://dx.doi.org/10.1161/01. CIR.0000112379.88385.67

AMERICAN OIL CHEMISTS' SOCIETY - AOCS. Official methods and recomended practices of the AOCS. 4th ed. Champaign: AOCS, 1998.

ANTONIASSI, R. et al. Avaliação da composição química de cultivares produzidos pela EMBRAPA. In: SIMPÓSIO LATINO AMERICANO DE CIÊNCIA DE ALIMENTOS, 2., 1977, Campinas. Resumos... Campinas: UNICAMP, 1997. p. 65.

APPOLINÁRIO, P. P. et al. Metabolismo, oxidação e implicações biológicas do ácido docosahexaenoico em doenças neurodegenerativas. Química Nova, v. 34, n. 8, p.1409-1416, 2011. http://dx.doi.org/10.1590/S0100-40422011000800021

ARRIEL, N. H. C.; VIEIRA, D. J.; FIRMINO, P. T. Situação atual e perspectivas da cultura do gergelim no Brasil. EMBRAPA, 2005.

BABA, N. H.; GHOSSOUB, Z.; HABBAL, Z. Differential effects of dietary oils on plasma lipids, lipid peroxidation and adipose tissue lipoprotein lipase activity in rats. Nutrition Research, v. 20 , n. 8 , p. 1113-1123, 2000. http://dx.doi.org/10.1016/S02715317(00)00196-2

BASBAG, S.; TONCER, O.; BASBAG, M. Fatty acid composition of Linum spp. collected from southeastern of Turkey. Chemistry of Natural Compounds, v. 45, p. 1-3, 2009. http://dx.doi.org/10.1007/ s10600-009-9332-z

BLIGH, E. G.; DYER, W. J. A rapid method of total lipid extraction and purification. Canadian Journal of Biochemistry and Physiology, n. 37, p. 911-917, 1959. PMid:13671378. http://dx.doi.org/10.1139/ o59-099

BROUGHTON, K. S.; BAYES, J.; CULVER, B. High a-linolenic acid and fish oil ingestion promotes ovulation to the same extent in rats. Nutrition Research, v. 30, p. 731-738, 2010. PMid:21056289. http:// dx.doi.org/10.1016/j.nutres.2010.09.005

BURDGE, G. C. Metabolism of alpha-linolenic acid in humans. Prostaglandins, leukotrienes and essential fatty acids, v. 75, n. 3, p. 161-168, 2006. PMid:16828546. http://dx.doi.org/10.1016/j. plefa.2006.05.013

CAREY, R. N.; FELBRUEGGE, C.; WESTGARD, J. O. Evaluation of the adaptation of the glucose oxidase/peroxidase-3-methyl-2- 
benzothiazoline hydrazone- $\mathrm{N}, \mathrm{N}$-dimethylaniline procedure to the technicon SMA 12/60 and comparation with other automed methods for glucose. Clinical Medicine, v. 20, p. 595-602, 1974.

CECCHI, H. M. Fundamentos teóricos e práticos em análise de alimentos. Campinas: Unicamp, 2003. p. 13.

CHOO, W.; JOHN, B.; DUFOUR, J. P. Physicochemical and quality characteristics of cold-pressed flaxseed oils. Journal of Food Composition Analysis, v. 20, p. 202-211, 2007. http://dx.doi. org/10.1016/j.jfca.2006.12.002

CHUNG, M. W. Y.; LEI, B.; LI-CHAN, E. C. Y. Isolation and structural characterization of the major protein fraction from NorMan flaxseed (Linum usitatissimum L.). Food Chemistry, v. 90, p. 271-279, 2005. http://dx.doi.org/10.1016/j.foodchem.2003.07.038

CORSINI, M. S.; JORGE, N. Estabilidade oxidativa de óleos vegetais utilizados em frituras de mandioca palito congelada. Ciência e Tecnologia de Alimentos, v. 26, p. 27-32, 2006. http://dx.doi. org/10.1590/S0101-20612006000100005

COSTUNER, Y.; KARABABA, E. Some physical properties of flaxseed (Linum usitatissimun L.). Journal of Food Engineering, v. 78, p. 297-305, 2008.

CUNNANE, S. C. et al. Nutritional attributes of traditional flaxseed in healthy young adults. Journal of Clinical Nutrition, v. 61, p. $62-68,1995$.

EMBRAPA. O agronegócio do gergelim no Brasil. Brasília: Ministério da Agricultura, Pecuária e Abastecimento, 2001. p. 325.

EPAMINONDAS, P. S. Caracterização físico-química e termooxidativa das sementes de linhaça (linum usitatissimum L.) e de seus óleos. 2009. 101 f. Dissertação (Mestrado em Ciência e Tecnologia de Alimentos)-Universidade federal da Paraíba, João Pessoa, 2009.

FERNANDES, M. C. A. et al. Avaliação dos efeitos da suplementação com farinha de linhaça (Linum usitatissimum L.) marrom e dourada sobre o perfil lipídico e a evolução ponderal em ratos Wistar. Revista Brasileira de Plantas Medicinais, v.12, n. 2, p. 201-207, 2010. http:// dx.doi.org/10.1590/S1516-05722010000200012

FLEG, H. M. An investigation of the determination of serum cholesterol by an enzymatic method. Clinical Biochemistry, v. 10, p. 79-84, 1973.

GALVÃO, E. L. et al. Avaliação do potencial oxidante e extração subcrítica do óleo. Ciência e Tecnologia de Alimentos, v. 28, n. 3, p. 551-557, 2008. http://dx.doi.org/10.1590/S010120612008000300008

HAGEN, J. H.; HAGEN, P. B. An enzimatic method for the estimation of glicerol in blood and its use to determine the effect of noradrenaline on the concentration of glycerol in blood. Canadian Journal of Biochemistry and Physiology, v. 40, p. 1129-39, 1962. PMid:13903591. http://dx.doi.org/10.1139/o62-127

HARRIS, W. S. et al. Omega-3 fatty acids and coronary heart disease risk: Clinical and mechanistic perspectives. Atherosclerosis, v. 197, p. 12-24, 2008. PMid:18160071. http://dx.doi.org/10.1016/j. atherosclerosis.2007.11.008

HARTMAN, L.; LAGO, R. C. A. Rapid preparation of fatty acid methyl esters from lipids. Laboratory Practice, v. 22, p. 475-494, 1973. PMid:4727126.

HOLLAND, B. et al. The composition of foods. Cambridge: McCance and Widdowson's, 1994. p. 8-9.

INSTITUTE OF MEDICINE. Dietary reference intakes for energy, carbohydrate, fiber, fat, fatty acids, cholesterol, protein, and amino acids (macronutrients). Washington: National Academy Press, 2005. p. 422-541.
KAITHWAS, G.; MAJUMDAR, D. K. Therapeutic effect of Linum usitatissimum (flaxseed/linseed) fixed oil on acute and chronic arthritic models in albino rats. Inflamatory, p. 1-10, 2010.

KAUL, N. et al. A comparison of fish oil, flaxseed oil and hempseed oil supplementation on selected parameters of cardiovascular health in healthy volunteers. Journal of the American College of Nutrition, v. 27 , n. 1, p. 51-58, 2008. PMid:18460481.

KÖKTEN, K. et al. Tannin, protein contents and fatty acid compositions of the seeds of several Vicia L. species from Turkey. Grasas y Aceites, n. 61, p. 404-408, 2010. http://dx.doi.org/10.3989/gya.021310

KRIS-ETHERTON, E. Bioactive compounds in foods: Their role in prevention on 71-cardiovascular disease and cancer. American Journal of Medicine, n. 113, p. 11-88, 2006.

KRUMMEL, D. Nutrição na doença cardiovascular. Krause: Alimentos, Nutrição e Dietoterapia. São Paulo: Roca, 2007. p. $552-558$.

LONDON. Department of Health and Social Security. Diet and cardiovascular disease. London: HMSO, 1984. p. 28. Report on Health and Social Subjects.

LUZIA, D. M. M.; JORGE, N. Antioxidant activity, fatty acid proile and tocopherols of Tamarindus indica L. seeds. Ciência e Tecnologia de Alimentos, v. 31, n. 2, p. 497-501, 2011. http://dx.doi.org/10.1590/ S0101-20612011000200034

MAIA, E. L.; RODRIGUEZ-AMAYA, D. B. Avaliação de um método simples e econômico para a metilação de ácidos graxos com lipídios de diversas espécies de peixes. Revista do Instituto Adolfo Lutz, n. 53, p. 27-35, 1993.

MARQUES, A. C. et al. Effect of flaxseed (Linum usitatissimum L.) prepared by different methods on the biological response of rats. Revista de Nutrição,v. 24, n. 1, p. 131-141, 2011. http://dx.doi. org/10.1590/S1415-52732011000100013

MATHEWS, K. R. et al. Effect of whole linseed (Linum usitatissimum) in the diet of finishing pigs of growth performance and on the quality and fatty acids composition of various tissues. British Journal of Nutrition, v. 83, p. 637-643, 2000. http://dx.doi.org/10.1017/ S0007114500000817

McKENNEY, J. M.; SICA, D. Prescription omega-3 fatty acids for the treatment of hypertriglyceridemia. American Journal of Health System Pharmacy, v. 64, n. 6, p. 595-605, 2007. PMid:17353568. http://dx.doi.org/10.2146/ajhp060164

MOREIRA, J. D. et al. Dietary omega-3 fatty acids attenuate cellular damage after a hippocampal ischemic insult in adult rats. Journal of Nutritional Biochemistry, v. 21, p. 351-356, 2010. PMid:19410444. http://dx.doi.org/10.1016/j.jnutbio.2009.01.013

MORISE, A. et al. Effects of dietary alpha linolenic acid on cholesterol metabolism in male and female hamsters of the LPN strain. Journal of Nutritional Biochemistry, v. 15, p. 51-61, 2004. PMid:14711461. http://dx.doi.org/10.1016/j.jnutbio.2003.10.002

NAGAO, K.; YANAGITA, T. Bioactive lipids in metabolic syndrome. Progress in Lipid Research, p. 127-146, 2008. PMid:18177744. http://dx.doi.org/10.1016/j.plipres.2007.12.002

ONODY, A. M. et al. Hyperlipidemia induced by a cholesterol-rich diet leads to enhanced peroxidative formation in rat hearts. Cardiovascular Research, v. 58, n. 3, p. 663-670, 2003. http://dx.doi. org/10.1016/S0008-6363(03)00330-4

ORDOÑEZ-PEREDA, J. A. Lipídeos. In: ORDOÑEZ-PEREDA, J. A. Tecnologia dos alimentos: Componentes dos alimentos e processos. São Paulo: Artmed, 2005. p. 33-49. 
PELLIZZON, M. A. et al. Flaxseed Reduces Plasma Cholesterol Levels in Hypercholesterolemic Mouse Models. Journal of the American College of Nutrition, v. 26, n. 1, p. 66-75, 2008.

PEIRETTI, P. G.; MEINERI, G. I. Chemical composition, organic matter digestibility and fatty acid content of linseed (Linum usitatissimum L.) harvested at five stages of growth. Journal of Food Science Agricultural, v. 88, p. 1850-1854, 2008. http://dx.doi. org/10.1002/jsfa.3284

POUDYAL, H. et al. Omega-3 fatty acids and metabolic syndrome: Effects and emerging mechanisms of action. Progress in Lipid Research, v. 50, p. 372-387, 2011. PMid:21762726. http://dx.doi. org/10.1016/j.plipres.2011.06.003

RAMADAN, M. F. et al. Changes in Lipid Profile by Vegetable Oil Blends Rich in Polyunsaturated Fatty Acids in Rats with Hypercholesterolemia. Food Science of Technology Institute, v. 15, p. 119-130, 2009. http://dx.doi.org/10.1177/1082013208105167

RAMESH, B. Beneficial effect of substitution of sesame oil on hepatic redox status and lipid parameters in streptozotocin diabetic rats. International Journal of Science and Nature, v. 2, n. 3, p. 488493, 2011.

RAMOS FILHO, M. M. et al. Perfil lipídico de quatro espécies de peixes da região pantaneira de Mato Grosso do Sul. Ciência e Tecnologia de Alimentos, v. 28, p. 361-365, 2008. http://dx.doi.org/10.1590/ S0101-20612008000200014

RAPOSO, H. F. Efeito dos ácidos graxos n-3 e n-6 na expressão de genes do metabolismo de lipídeos e risco de aterosclerose. Revista de Nutrição, v. 23, n. 5, p. 871-879, 2010. http://dx.doi.org/10.1590/ S1415-52732010000500017

REEVES, P. G.; NIELSEN, F. H.; FAHEY, G. C. J. AIN-93 Purified Diets for Laboratory Rodents: Final Report of the American Institute of Nutrition Ad Hoc Writing Committee on the Reformulation of the AIN-76A Rodent Diet. The Journal of Nutrition, p. 1939-1951, 1993. PMid:8229312.

RESHMA, M. V. et al. Extraction, separation and characterisation of sesame oil lignan for nutraceutical applications. Food Chemistry, v. 120, p. 1041-1046, 2010. http://dx.doi.org/10.1016/j. foodchem.2009.11.047

RODRIGUES-LEVYA, D. et al. The cardiovascular effects of flaxseed and its omega-3 fatty acid, alpha-linolenic acid. Canadian Journal of Cardiology, v. 26, n. 9, p. 489-496, 2010. http://dx.doi. org/10.1016/S0828-282X(10)70455-4

ROTHENBURG, H. C.; PEREIRA, F. M. Avaliação dos efeitos da ingestão de sementes de linhaça (Linum usitatissimum) em ratos wistar fêmeas hipercolesterolêmicos. Ciência e Tecnologia de Alimentos, v. 7, p. 1-8, 2006.

SAMMOUR, S. H. Proteins of linseed (Linum usitatissimum), extraction and characterization by eletrophoresis. Botanical Academica Sinia, v. 40, p. 121-126, 1999.
SANTOS, J. S.; BESSA, R. J. B.; SANTOS, F. S. Effect of genotype, feeding system and slaughter weigt on the quality of light lambs. II. Fatty acid composition of meat. Livestock Product Science, n. 77, p. 187-194, 2002. http://dx.doi.org/10.1016/S0301-6226(02)00059-3

SENER, A. et al. The metabolic syndrome of omega3-depleted rats II. Body weight, adipose tissue mass and glycemic homeostasis. International Journal of Molecular Medicine, v. 24, p. 125-129, 2009. PMid:19513544.

SOCIEDADE BRASILEIRA DE ANGIOLOGIA E CIRURGIA VASCULAR. SBACV, v. 7, n. 2, 2005.

STODOLNIK, L. et al. Rancidity inhibition study in frozen whole mackerel (Scomber scombrus) following flaxseed (Linum usitatissimum) extract treatment. Grasas y Aceites, n. 56, p. 198-204, 2005.

TZANG, B. S. et al. Effects of dietary flaxseed oil on cholesterol metabolism of hamsters. Food Chemistry, v. 114, p. 1450-1455, 2009. http://dx.doi.org/10.1016/j.foodchem.2008.11.030

ULBRICHT, T. L. V.; SOUTHGATE, D. A. T. Coronary heart disease: seven dietary factors. Lancet, n. 338, p. 985-992, 1991. http://dx.doi. org/10.1016/0140-6736(91)91846-M

ÜNAL, M. K.; YALÇIN, H. Proximate composition of Turkish sesame seeds and characterization of their oils. Grasas y Aceites, v. 59, p. 23-26, 2008.

UNITED STATES. Department of Agriculture. National nutrient database for standard reference, release 19. [cited 2006]. Available from: <http://www.nal.usda.gov/fnic/foodcomp/search/>.

UZUN, B. et al. Fat and fatty acids of white lupin (Lupinus albus L.) in comparison to sesame (Sesamum indicum L.). Food Chemistry, n. 102, p. 45-49, 2007. http://dx.doi.org/10.1016/j. foodchem.2006.03.059

VIJAIMOHAN, K. et al. Beneficial effects of alpha linolenic acid rich flaxseed oil on growth performance and hepatic cholesterol metabolism in high fat diet fed rats. Life Science, n. 79, p. 448-454, 2006. PMid:16490217. http://dx.doi.org/10.1016/j. lfs.2006.01.025

WAITZBERG, D. L.; BORGES, V. Gorduras: Nutrição Oral, Enteral e Parenteral na Prática Clínica. 2005. São Paulo, p. 64-67.

WHELAN, J.; RUST, C. Innovative dietary sources of n-3 fatty acids. Revista de Nutrição, n. 26, p. 75-103, 2006.

WORLD HEALTH ORGANIZATION. Joint Consultation: fats and oils in human nutrition. Nutrition Review, v. 53, p. 202-205, 1995. PMid:7494623.

YEN, G. C.; LAY, S. H. Oxidative stability of instant noodles fried with sesame oil-vegetable oil blends. Journal of Chinese Agriculture Chemical Society, n. 2, p. 196-201, 1990. 